\title{
Seasonality and chemical elicitation of defense oleoresin production in field-grown slash pine under subtropical climate
}

\section{Kelly Cristine da Silva Rodrigues-Corrêa, Arthur Germano Fett-Neto*}

Plant Physiology Laboratory, Center for Biotechnology and Department of Botany,

Universidade Federal do Rio Grande do Sul (UFGRS), Porto Alegre, RS, Brazil.

*Corresponding author: fettneto@cbiot.ufrgs.br

Received: April 17, 2013; Accepted: April 30, 2013

ABSTRACT: Oleoresin is a key defense strategy of advanced gymnosperms, based on the combination of a complex anatomical structure of resin ducts and elaborate terpene biochemistry. Given the vast array of oleoresin economic applications in the chemical, pharmaceutical, agrochemical, and biofuel industries, translating factors that regulate terpene biosynthesis into higher oleoresin yield is a challenge for the forestry industry. Field tests with approximately 3,500 28-year-old slash pine (Pinus elliottii Engelm. var. elliottii) trees were carried out from 2005 to 2008, under the subtropical climate of Southern Brazil, in order to examine the seasonal profile of oleoresin production stimulation in response to different chemical adjuvants, after mechanical injury. Yields of trees treated with oleoresin-inducing pastes containing alternative adjuvants were compared to the standard commercial one used on an industrial scale (based on the ethylene-releasing compound 2-chloroethylphosphonic acid - CEPA). Significant increases in pine oleoresin yield were observed by modulating its biosynthesis and using chemical stimulants affecting defense responses (benzoic acid, used in addition to CEPA) and biosynthetic enzymes (metal cofactors of terpene synthases, iron or potassium, used as replacements for CEPA). Oleoresin stimulation was consistent over at least four consecutive years. Overall effectiveness of oleoresin yield adjuvant stimulation was higher in the faster growth seasons, although potassium was effective in all of them. Combining metal cofactors did not show synergistic or additive interactions. The results suggest that higher oleoresin yields can be obtained by using individual adjuvants of the same signaling pathway in a season-specific fashion.

KEYWORDS: mechanical wounding, benzoic acid, metal cofactors, potassium, iron, terpene synthases, resin tapping.

\section{INTRODUCTION}

Slash pine (Pinus elliottii Engelm.) is characterized by the production of substantial amounts of oleoresin, which is a renewable source of terpenes, the largest class of plant secondary metabolites biosynthetically derived from isopentenyl diphosphate - IPP (Rodrigues-Corrêa et al. 2012). Briefly, terpenoid biosynthesis initiates with the formation of IPP (or its isomer DMPP - dimethylallyl diphosphate) from mevalonate (in the cytosolic pathway) or from MEP (2-C-methyl-D-erythritol 4-phosphate), in the plastidic pathway.
Following the formation of the basic hemiterpenoid building blocks, other IPP units are added by prenyltransferases (or IDS short-chain isoprenyl diphosphate synthases) (Schmidt et al. 2011). This is done to synthesize geranyl diphosphate - GPP $\left(C_{10}\right)$ and geranyl GPP $\left(\mathrm{C}_{20}\right)$ (mostly in plastids) and farnesyl diphosphate - $\operatorname{FPP}\left(\mathrm{C}_{15}\right)$ (mostly in cytosol), acyclic precursors of mono, di, and sesquiterpenes, respectively (Huber et al. 2004, Schmidt et al. 2011). The final steps of terpenoid biosynthesis (cyclization of the acyclic precursors) are catalyzed by the terpene synthases (TPS) or cyclases, which are enzymes capable of generating 
unique or multiple terpenoid products (Hall et al. 2013). TPS require divalent ions for catalysis (Huber et al. 2004, Keeling and Bohlmann 2006), and can have their activity improved by some monovalent cations in gymnosperms (Savage et al.1994).

Besides the product versatility displayed by the TPS, the wide diversity and chemical complexity of oleoresin terpenoids may be also attributed to alternative modifying reactions including methylations, oxidations, and additional prenylation events. Studies carried out with different conifer species have shown that TPS are able to respond to different stimuli by modulating both quality (mono, sesqui, and diterpenes composition profiles) and quantity of the oleoresin produced, according to the type of stimulus perceived (McKay et al. 2003). Furthermore, members of the multigene TPS family have shown to be wound-induced (McKay et al. 2006), and upregulated by insect attack (McKay et al. 2003) and methyl jasmonate (MejA) exogenous application (Fäldt et al. 2003). The exogenous application effects of defense-related chemical elicitors, such as salicylic acid (SA) and MeJA, on conifer defense metabolism, have been investigated in Pseudotsuga menziesii, Sequoiadendron giganteum (Hudgins and Franceschi 2004), Pinus elliottii (Rodrigues and Fett-Neto 2009), and Picea abies (Krajnc et al. 2011), showing variable responses depending on the species examined.

Pine oleoresin represents the major defense mechanism of conifers against their predators, and it may be either constitutively biosynthesized and stored in specialized structures, the resin ducts $(\mathrm{RD})$ (preformed oleoresin) or its biosynthesis can be induced by external challenges as a characteristic defense response (inducible oleoresin) that takes place, for example, after traumatic resin duct formation (McKay et al. 2003, Phillips 2012). Commercially, both oleoresin main fractions (turpentine and rosin) exhibit several applications in chemical industries, including the synthesis of solvents, perfumes, waterproof materials, paper sizing, printing inks, food additives, among others (Rodrigues-Corrêa et al. 2012), being of special interest the oleoresin produced by slash pine due to its physicochemical properties (RodriguesCorrêa and Fett-Neto, 2012).

Biotic and abiotic stresses, including mechanical injury, pathogen attack, water availability, seasonality, and chemical stimulating applications, for instance, have been reported as key factors affecting pine oleoresin biosynthesis (Lombardero et al. 2006, Rodrigues and Fett-Neto 2009, Ferreira et al. 2011). Most resin-stimulating pastes are based on a mixture of pyrogenic silica, emulsifier, and active ingredients such as sulphuric acid and 2-chloroethylphosphonic acid (CEPA), an ethylene-releasing compound, at 20 and $4.5 \%$ $\mathrm{w} / \mathrm{v}$, respectively (Rodrigues et al. 2011). In order to further increase oleoresin yield in slash pine forests, the current commercial production of oleoresin biomass in Southern Brazil has been based on physiological responses previously observed by modulation of some factors, and by testing the application effect of resin stimulating pastes with different chemical formulations (Rodrigues et al. 2008, Rodrigues and Fett-Neto 2009, Rodrigues et al. 2011). Furthermore, alternative chemical elicitors capable of replacing CEPA, which represents the highest cost for oleoresin producers in resin tapping operations (Rodrigues et al. 2011), have also been actively sought. However, these studies have been done essentially on a whole-year oleoresin harvest basis. The present study was focused on the effects of alternative chemical elicitor exogenous applications on seasonal oleoresin production in slash pine, compared to trees treated with commercial paste containing CEPA, in consecutive years.

\section{MATERIAL AND METHODS}

All trials were carried out in field-grown 28-year-old slash pine forests cultivated in Southern Brazil, which were not previously tapped (Rio Grande do Sul state, city of São José do Norte, approximately $32^{\circ}$ of south latitude and $52^{\circ}$ of west longitude). Trees were tapped biweekly (except in "frequency test"), according to the bark streak (Pio and Valente 1998, Rodrigues et al. 2008) or the American method (Cunningham 2012) that removes the bark, phloem, and vascular cambium tissues to expose the sapwood, surface where the chemical stimuli (stimulating pastes) are applied.

The seasonal oleoresin production was evaluated from 2005 to 2008 in metal cofactors tests. At the end of each season, the plastic bags attached to the trees were collected and weighed on a digital balance, after disposing the top water carefully. Seasons for these assays were limited to the following monthly distribution: Winter (June - August), Spring (September - November), Summer (December - February), and Fall (March-May). The performance of the commercial paste $\left(20 \% \mathrm{H}_{2} \mathrm{SO}_{4}\right.$ and $4.5 \%$ CEPA), used in large scale in Southern Brazilian resin tapping operations (Rodrigues and Fett-Neto 2009), was compared with that of pastes containing TPS metal cofactors $(\mathrm{K}, \mathrm{Fe}, \mathrm{Mn})$ or ethylene receptor $(\mathrm{Cu})$ ones (Savage et al. 994, Rodrigues et al. 2011), either isolated or combined in the absence of CEPA, and pastes with benzoic acid (BA), which is a SA precursor (Shah 2003), in the presence of CEPA.

The frequency effect of the commercial paste application on oleoresin yield was also evaluated.

Potassium: In order to assess the effect of potassium on CEPA replacement, 550 individuals per treatment (paste containing $500 \mathrm{~mol} \mathrm{~m}^{-3}$ of $\mathrm{K}_{2} \mathrm{SO}_{4}$ [potassium sulfate] without CEPA versus commercial paste - Control) were tested in two different sites, totaling 2,200 trees tested. 
Iron : In the same way, iron effect was evaluated by testing 550 trees per treatment (paste containing $10 \mathrm{~mol} \mathrm{~m}^{-3}$ of $\mathrm{FeSO}_{4} \cdot \mathrm{H}_{4} \mathrm{O}$ [ferrous sulfate] without CEPA versus commercial paste - Control).

Combined metal cofactors: The TPS metal cofactors $\mathrm{K}^{+}$ $\left(500 \mathrm{~mol} \mathrm{~m}^{-3}\right), \mathrm{Fe}^{2+}\left(10 \mathrm{~mol} \mathrm{~m}^{-3}\right), \mathrm{Mn}^{+}\left(1 \mathrm{~mol} \mathrm{~m}^{-3}\right)$ (provided as $\left.\mathrm{MnSO}_{4}\right)$, along with the ethylene receptor component $\mathrm{Cu}^{2+}(1$ mol m${ }^{-3}$ ) (provided as $\mathrm{CuSO}_{4}$ ), were combined in two different ways for the purpose of observing a possible synergistic or additive effect in the oleoresin production.

Benzoic acid: Two hundred trees were evaluated per treatment (commercial paste containing $10 \mathrm{~mol} \mathrm{~m}^{-3}$ of BA versus commercial paste-Control).

\section{Frequency of wounding and commercial paste appli-}

cation: The influence of the chemical stimulus frequency applied on the bark streak was measured in three treatments: mechanical wound only (bark streak); application of the commercial paste every 28 days; application of the commercial paste every 14 days. One hundred individuals were tested per site. All trials were performed in two places and the results are presented as the mean values of both locations. In metal cofactors and BA tests, the data were analyzed by using the Student's $t$-test comparison of treatments versus control samples, with $\mathrm{p} \leq 0.05$. Analyses of variance (ANOVA) followed by Dunnett's $\mathrm{C}$ were used for data evaluation in the wound frequency test.

\section{RESULTS AND DISCUSSION}

Significant differences were observed in the frequency test of commercial paste application. As expected, considering the stimulant effects of the SA and CEPA on oleoresin production (Rodrigues and Fett-Neto, 2012), slash pine trees showed higher annual oleoresin yields when commercial paste was applied on the bark streak biweekly $(3.666 \pm 0.683 \mathrm{~kg})$, compared to monthly application $(2.749 \pm 0.395 \mathrm{~kg})$ and no chemical elicitor application $(1.632 \pm 0.267 \mathrm{~kg})$. Increases between 1.5 to 2.5 fold in oleoresin yield by chemical stimulation compared to wounding alone were often observed in various field experiments (Rodrigues et al. 2011). Several reports have shown the effect of abiotic factors on oleoresin biosynthesis and monoterpene emissions. In slash pine (Tingey et al. 1980) and P. halepensis (Peñuelas and Llusià 1999), the rates of monoterpene emissions were enhanced with temperature increase. Temperature oscillations were also shown to influence oleoresin production of four pine species tested in Brazilian stands. Pinus elliottii var. elliottii, P. oocarpa, P. caribaea var. bahamensis, and P. kesyia trees, tapped during Spring and Summer, had inducible oleoresin yields reduced during the lowest temperatures registered (Brito et al. 1978).
Monoterpene emissions have exhibited a seasonal pattern. In their seasonal evaluation from three coniferous spp. (Cryptomeria japonica, Chamaecyparis obtuse, and P. koraiensis), the highest ones were observed in Spring and Summer (Kim et al. 2005). Comparable results were found for $P$. densiflora growing in East Asia (Lim et al. 2008) and P. sylvestris growing in Southern Germany (Holzke et al. 2006). In different regions; however, it has exhibited a variable profile of monoterpene emissions, displaying higher concentrations in early Summer (pure Scots pine stand) (Räisänen et al. 2009) and in Summer and Fall (increasing in association with some spruces, aspen, and birch) (Aaltonen et al. 2011) in Eastern and Southern Finland, respectively.

In our tests, a seasonal response was also seen for paste supplemented with $\mathrm{Fe}^{2+}$. Total replacement of CEPA by this metal was shown to be possible only in Spring and Summer (Figure 1). In P. taeda treated with fungal inoculation, the induced oleoresin average flow was higher in Summer when compared to Spring (Tisdale et al. 2003). The authors suggest that this pattern may be correlated with the early wood and latewood formations, which occur in Spring and Summer, respectively, and they would modulate the photosynthate availability for oleoresin formation. However, previous experiments carried out in subtropical climate have shown to be Spring the most productive season in terms of constitutive and inducible oleoresin productions (Rodrigues and Fett-Neto 2009), except in extreme conditions. For example, oleoresin yields in slash pine treated with different chemical pastes were higher in Winter than in Summer in the year 2005 (Rodrigues and Fett-Neto, unpublished results). This abnormal production was more severe in extremely dry sites and years. Hence, water availability may also be a decisive factor affecting oleoresin biosynthesis.

The activity of constitutive monoterpene cyclases was reduced by water (and light) stress in Abies grandis (Grand Fir) saplings and mature trees. Furthermore, there was an interruption of wound-induced response (oleoresinosis) caused by the dry condition (Lewinsohn et al. 1993). Transient flooding treatment enhanced the oleoresin yield of one-year-old slash pine seedlings in greenhouse conditions (Ferreira et al. 2011). Irrigation tests performed on P. sylvestris L. dry sites showed a positive correlation between radial growth and moisture in Spring, albeit resin duct formation had been stimulated mainly by high Summer temperatures (Rigling et al. 2003).

In annual terms, potassium treatment presented superior yields of oleoresin along the four-year evaluation compared to commercial paste, being the last one the most productive year. Interestingly, the positive effect of potassium was observed throughout the seasons of the years examined (Figure 2). This stimulation was especially conspicuous in the transiently 
waterlogged site. Highest oleoresin production was also observed in the fourth year of resin tapping in slash pine for both faces of the trunk (Figueiredo-Filho et al. 1992). In the present tests, the increased oleoresin flow seen in the last year evaluated does not seem to be related to the differential density or size of constitutive RDs, since both parameters decrease with age (in slash pine the number of RDs reaches a stable level at approximately 20 years of age) (Hodges et al. 1981). Also, all trees tested were almost three decades old. These results confirm previous observations concerning the role of potassium as a suitable substitute of CEPA (Rodrigues et al. 2011) in stimulating paste formulations. Herein, we showed that, at least for the sites and conditions tested, potassium stimulatory effect on oleoresin yield as a replacement for CEPA in resin inducing paste was not strongly affected by season.

Previously, annual oleoresin production of 28-year-old slash pine trees was assessed by using isolated metal cofactors of TPS and ethylene receptors at two different sites (Rodrigues et al. 2011). Higher yields were obtained using pastes supplemented with low concentrations of copper $\left(1 \mathrm{~mol} \mathrm{~m}^{-3}\right)$ (a component of ethylene receptors), moderate of iron $\left(10\right.$ or $\left.100 \mathrm{~mol} \mathrm{~m}^{-3}\right)$, and high of potassium $\left(500 \mathrm{~mol} \mathrm{~m}^{-3}\right)$. In the present study, no synergistic effect on oleoresin biosynthesis was observed in pastes combining TPS metal cofactors. The absence of CEPA in pastes caused significantly lower oleoresin yields in the colder seasons, this difference becoming less pronounced in Spring (Figure 3). Moreover, efficient replacement of CEPA was observed only in the Summer regardless the presence of copper. These results suggest that there was no additive effect by combining metal cofactors involved in similar or correlated biochemical functions.

Similarly to what was observed in tests with iron, commercial paste containing BA in its formulation presented better performance as oleoresin inducer in Spring and Summer

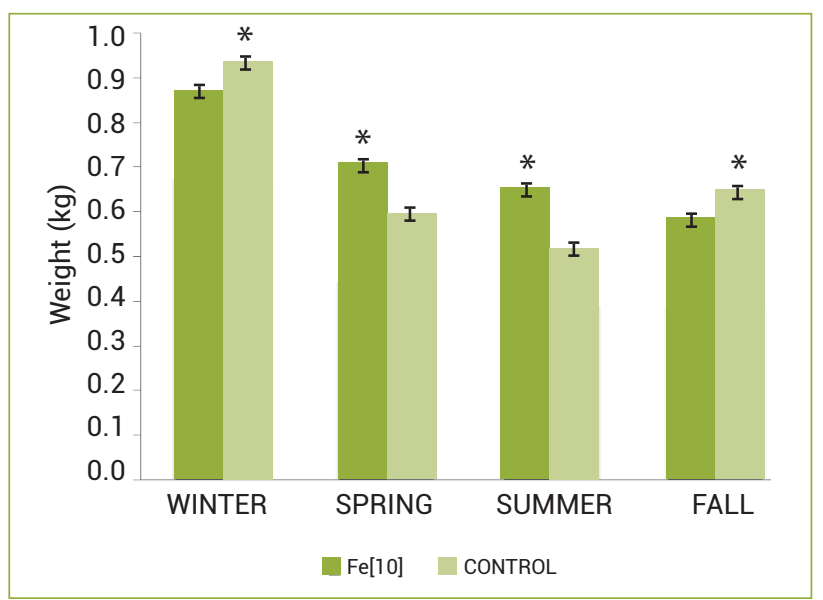

Figure 1. Seasonal variation of slash pine oleoresin production: iron $\left(10 \mathrm{~mol} \mathrm{~m}^{-3}\right)$ effect as a full replacement of CEPA. Control paste is based on CEPA. Asterisks indicate the significant difference between treatments at a particular season. than in Fall and Winter (Figure 4). Little is known about conifer physiological response to BA treatment. However, there are few works concerning the effects of SA exogenous application. Methyl salicylate (10, 25, 50 and $100 \mathrm{mM})$ treatment in Pseudotsuga menziesii and Sequoiadendron giganteum did not induce either oleoresin or phenolic biosynthesis, typical defense-related responses displayed by conifers (Hudgins and Franceschi 2004). Following SA treatment $\left(10 \mathrm{~mol} \mathrm{~m}^{-3}\right)$, slash pine showed superior oleoresin yields when compared to controls (pastes with CEPA), and equivalent yields in pastes prepared without CEPA in all seasons tested (Rodrigues and Fett-Neto 2009). SA exogenous application $(100 \mathrm{mM})$ in Picea abies inhibited the colonization by Ips typographus, possibly as a response mediated by the induction of antioxidant defense mechanisms (Krajnc, Kristl and Ivancic, 2011). Methyl salicylate, SA, and its precursor $\mathrm{BA}$ are involved in pathogen-defense mechanism signaling (Shah 2003) and possibly mimic the pathogen attack signals, by inducing oxidative stress and promoting the transcription of defense-related genes (Krajnc et al. 2011).

Albeit the effects of CEPA have not been entirely replaced by pastes supplemented with iron in all seasons tested, its application remains viable since most of it exhibited equivalent or superior yields compared to the commercial paste in Spring and/or Summer. Taking into account that they represent the main period of the year in which commercial resin tapping operations are carried out, and the significantly higher market price of CEPA, its replacement by means of the development of seasonal (metal cofactors-based) pastes would provide a significant gain for resin tapping activity. The use of BA as an additional adjuvant with CEPA is also viable in the faster growth seasons, improving yields.

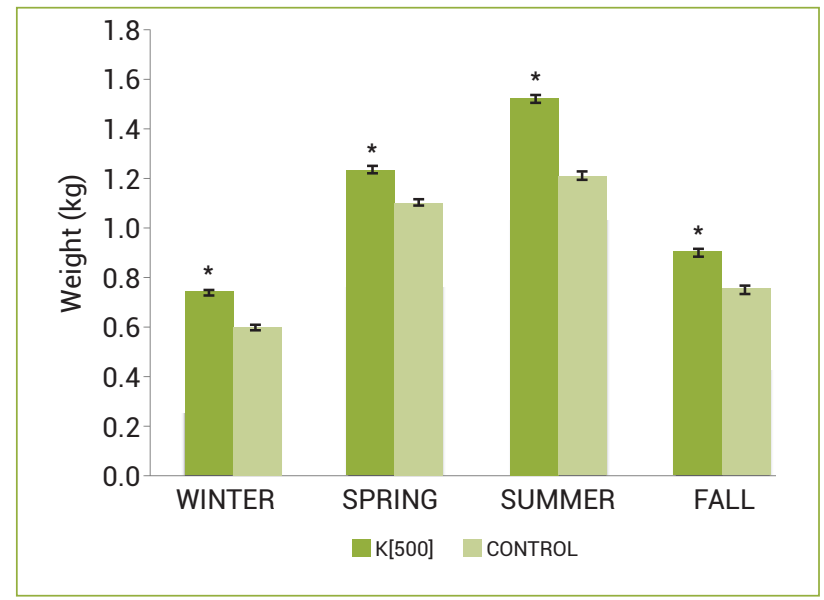

Figure 2. Seasonal variation of slash pine oleoresin production: potassium $\left(500 \mathrm{~mol} \mathrm{~m}^{-3}\right)$ effect as a full replacement of CEPA. Control paste is based on CEPA. Asterisks indicate a significant difference between treatments at a particular season. 


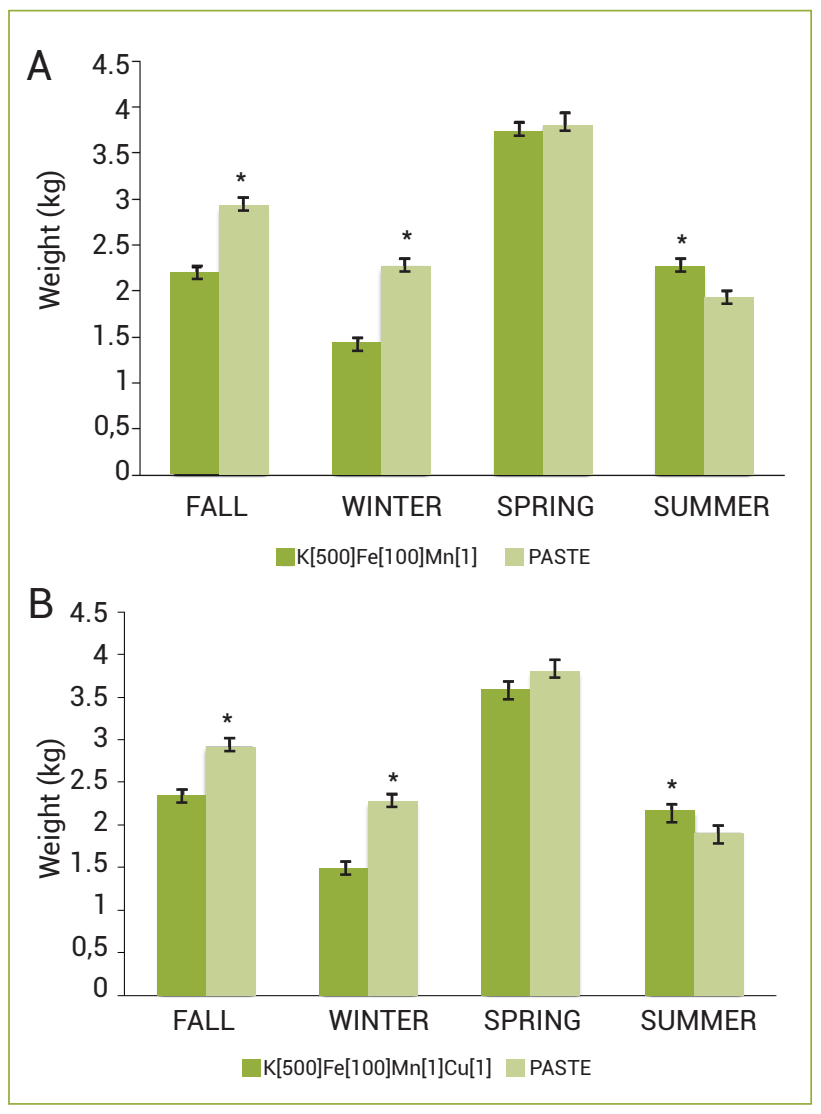

Figure 3. Seasonal production of slash pine oleoresin: combined metal adjuvant effects as a full replacement of CEPA. Control paste is based on CEPA. (A) Terpene synthases (TPS) metal cofactors combined (K $500 \mathrm{~mol} \mathrm{~m}^{-3}+\mathrm{Fe} 100 \mathrm{~mol} \mathrm{~m}^{-3}+$ Mn $1 \mathrm{~mol} \mathrm{~m}^{-3}$ ). (B) TPS metal cofactors combined plus copper ( $\mathrm{K} 500 \mathrm{~mol} \mathrm{~m}^{-3}+\mathrm{Fe} 100 \mathrm{~mol} \mathrm{~m}^{-3}+\mathrm{Mn} 1 \mathrm{~mol} \mathrm{~m}^{-3}+\mathrm{Cu} 1 \mathrm{~mol} \mathrm{~m}^{-3}$ ). Asterisks indicate a significant difference between treatments at a particular season.

Therefore, data to date suggests that seasonal pastes could be designed to achieve the highest oleoresin yields with paste cost reduction, by replacing CEPA with metal adjuvants or combining it with BA, particularly in Summer and Spring.

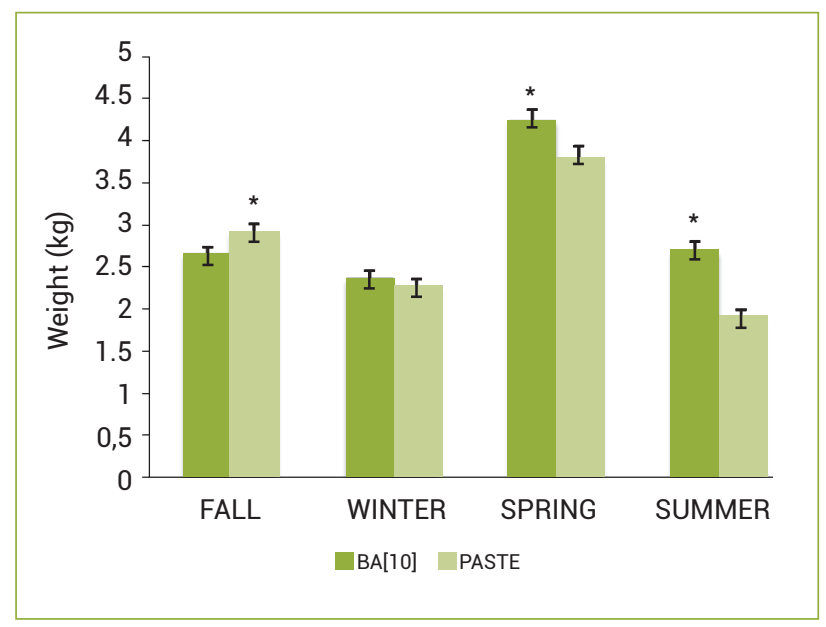

Figure 4. Seasonal variation of slash pine oleoresin production: benzoic acid effect as an adjuvant $\left(10 \mathrm{~mol} \mathrm{~m}^{-3}\right)$ added with CEPA. Asterisks indicate a significant difference between treatments at a particular season.

Further investigations are needed to verify if BA is capable of replacing CEPA, and to check for potential positive interactions between two different signaling pathways on oleoresin biosynthesis, such as BA (or SA) combined with one of the TPS metal cofactors.

\section{ACKNOWLEDGMENTS}

This study was supported by a grant-in-aid of research provided by the Pinus Foresters Consortia (Irani Celulose/ Trevo Florestal/Florestal Palmares, Rio Grande do Sul, Brazil), and by grants and scholarships from the State Foundation for Research Support of Rio Grande do Sul (Fapergs, Brazil), the National Committee for Graduate Programs Evaluation (CAPES-PNPD, Brazil), and the National Council for Scientific and Technological Development (CNPq, Brazil).

\section{REFERENCES}

Aaltonen $\mathrm{H}$, Pumpanen $\mathrm{J}$, Pihlatie $\mathrm{M}$, Hakola $\mathrm{H}$, Hellen $\mathrm{H}$, Kulmala $L$, et al (2011) Boreal pine forest floor biogenic volatile organic compound emissions peak in early summer and autumn. Agricultural and Forest Meteorology 151:682-691.

Brito JO, Barrichelo LEG, Gutierrez LE, Trevisan JF (1978) Resina de Pinus implantados no Brasil: resinagem e qualidade de resinas de pinheiros tropicais: comparações entre espécies e época de resinagem. Instituto de Pesquisas e Estudos Florestais; ESALQUSP, Circular técnica 35.

Cunningham A (2012) Pine resin tapping techniques. In: Fett-Neto AG, Rodrigues-Corrêa KCS (eds), Pine resin: biology, chemistry and applications, pp. 1-8. Research Signpost, Kerala, India.
Fäldt J, Martin D, Miller B, Rawat S, Bohlmann J (2003) Traumatic resin defense in Norway spruce (Picea abies): methyl jasmonateinduced terpene synthase gene expression, and cDNA cloning and functional characterization of (+)-3-carene synthase. Plant Molecular Biology 51:119-133.

Ferreira AG, Fior CS, Gualtieri SCJ (2011) Oleoresin yield of Pinus elliottii Engelm. seedlings. Brazilian Journal of Plant Physiology 23:313-316.

Figueiredo-Filho A, Machado SA, Hosokawa RT, Kikute P (1992) Avaliação econômica da resinagem em floresta de Pinus elliottii Engelm. var. elliottii. Instituto de Pesquisas e Estudos Florestais, Circular Técnica 45:48-63. 
Hall $D E$, Zerbe $P$, Jancsik $S$, Quesada AL, Dullat $H$, Madilao LL, et al (2013) Evolution of conifer diterpene synthases: diterpene resin acid biosynthesis in Lodgepole Pine and Jack Pine involves monofunctional and bifunctional diterpene synthases. Plant Physiology 161:600-616.

Hodges JD, Elam WW, Bluhm DR (1981) Influence of resin duct size and number on oleoresin flow in the southern pines. USDA Forest Service Research Note SO-266, Southern Forest Experiment Station, New Orleans.

Holzke C, Hoffmann T, Jaeger L, Koppmann R, Zimmer W (2006) Diurnal and seasonal variation of monoterpene and sesquiterpene emissions from Scots pine (Pinus sylvestris L.). Atmospheric Environment 40:3174-3185.

Huber DPW, Ralph S, Bohlmann J (2004) Genomic hardwiring and phenotypic plasticity of terpenoid-based defenses in conifers. Journal of Chemical Ecology 30:2399-2418.

Hudgins JW, Franceschi VR (2004) Methyl jasmonate-induced ethylene production is responsible for conifer phloem defense responses and reprogramming of stem cambial zone for traumatic resin duct formation. Plant Physiology 135:2134-2149.

Keeling Cl, Bohlmann J (2006) Diterpene resin acids in conifers. Phytochemistry 67:2415-2423.

Kim JC, Kim KJ, Kim DS, Han JS (2005) Seasonal variations of monoterpene emissions from coniferous trees of different ages in Korea. Chemosphere 59:1685-1696.

Krajnc AU, Kristl J, Ivancic A (2011) Application of salicylic acid induces antioxidant defense responses in the phloem of Picea abies and inhibits colonization by Ips typographus. Forest Ecology and Management 261:416-426.

Lewinsohn E, Gijzen M, Muzika RM, Barton K, Croteau R (1993) Oleoresinosis in Grand Fir (Abies grandis) saplings and mature trees (Modulation of this wound response by light and water stresses). Plant Physiology 101:1021-1028.

Lim JH, Kim JC, Kim KJ, Son YS, Sunwoo Y, Han JS (2008) Seasonal variations of monoterpene emissions from Pinus densiflora in East Asia. Chemosphere 73:470-478.

Lombardero MJ, Ayres MP, Ayres BD (2006) Effects of fire and mechanical wounding on Pinus resinosa resin defenses, beetle attacks, and pathogens. Forest Ecology and Management 225:349-358.

McKay SAB, Godard KA, Toudefallah M, Martin DM, Alfaro R, King J, et al (2006) Wound-induced terpene synthase gene expression in Sitka spruce that exhibit resistance or susceptibility to attack by the white pine weevil. Plant Physiology 140:1009-1021.

McKay SAB, Hunter WL, Godard KA, Wang SX, Martin DM, Bohlmann $\mathrm{J}$, et al (2003) Insect attack and wounding induce traumatic resin duct development and gene expression of (-)-Pinene Synthase in Sitka spruce. Plant Physiology 133:600-616.

Peñuelas J, Llusià J (1999) Short-term responses of terpene emission rates to experimental changes of PFD in Pinus halepensis and Quercus ilex in summer field conditions. Environmental and Experimental Botany 42:61-68.

Phillips M (2012) Inducible and constitutive defenses in pine: the ecological role of pine oil. In: Fett-Neto AG, Rodrigues-Corrêa KCS (eds), Pine resin: biology, chemistry and applications, pp. 49-66. Research Signpost, Kerala, India.

Pio CA, Valente AA (1998) Atmospheric fluxes and concentrations of monoterpenes in resin-tapped pine forests. Atmospheric Environment 32:683-691.

Räisänen T, Ryyppö A, Kellomäki S (2009) Monoterpene emission of a boreal Scots pine (Pinus sylvestris L.) forest. Agricultural and Forest Meteorology 149:808-819.

Rigling A, Bruhlhart $\mathrm{H}$, Braker OU, Forster T, Schweingruber $\mathrm{FH}$ (2003) Effects of irrigation on diameter growth and vertical resin duct production in Pinus sylvestris L. on dry sites in the central Alps, Switzerland. Forest Ecology and Management 175:285-296.

Rodrigues-Corrêa KCS, Fett-Neto AG (2012) Physiological control of pine resin production. In: Fett-Neto AG, Rodrigues-Corrêa KCS (eds), Pine resin: biology, chemistry and applications, pp. 25-48. Research Signpost, Kerala, India.

Rodrigues-Corrêa KCS, de Lima JC, Fett-Neto AG (2012) Pine oleoresin: tapping green chemicals, biofuels, food protection, and carbon sequestration from multipurpose trees. Food and Energy Security 1:81-93.

Rodrigues KCS, Apel MA, Henriques AT, Fett-Neto AG (2011) Efficient oleoresin biomass production in pines using low cost metal containing stimulant paste. Biomass and Bioenergy 35:4442-4448.

Rodrigues KCS, Azevedo PCN, Sobreiro LE, Pelissari P, Fett AG (2008) Oleoresin yield of Pinus elliottii plantations in a subtropical climate: Effect of tree diameter, wound shape and concentration of active adjuvants in resin stimulating paste. Industrial Crops and Products 27:322-327.

Rodrigues KCS, Fett-Neto AG (2009) Oleoresin yield of Pinus elliottii in a subtropical climate: Seasonal variation and effect of auxin and salicylic acid-based stimulant paste. Industrial Crops and Products 30:316-320.

Rodriguez FI, Esch JJ, Hall AE, Binder BM, Schaller GE, Bleecker $A B$ (1999) A copper cofactor for the ethylene receptor ETR1 from Arabidopsis. Science 283:996-998.

Savage TJ, Hatch MW, Croteau R (1994) Monoterpene synthases of Pinus contorta and related conifers. A new class of terpenoid cyclase. Journal of Biological Chemistry 269:4012-4020.

Schmidt A, Nagel R, Krekling T, Christiansen E, Gershenzon J, Krokene P (2011) Induction of isoprenyl diphosphate synthases, plant hormones and defense signalling genes correlates with traumatic resin duct formation in Norway spruce (Picea abies). Plant Molecular Biology 77:577-590.

Shah J (2003) The salicylic acid loop in plant defense. Current Opinion in Plant Biology 6:365-371.

Tingey DT, Manning M, Grothaus LC, Burns WF (1980) Influence of light and temperature on monoterpene emission rates from slash pine. Plant Physiology 65:797-801.

Tisdale RA, Nebeker TE, Hodges JD (2003) The role of oleoresin flow in the induced response of loblolly pine to a southern pine beetle associated fungus. Canadian Journal of Botany 81:368-374. 